\title{
Viral Enfeksiyonlarda Telomeraz Aktivitesi
}

\author{
Elif BAYRAM ${ }^{1}$, Metin ÇENESiZ² ${ }^{2}$ Semra OKUR GÜMÜŞOVA ${ }^{1 *}$ \\ ${ }^{1}$ Ondokuz Mayıs Üniversitesi, Veteriner Fakültesi, Viroloji Anabilim Dalı, Samsun, Türkiye. \\ 2 Ondokuz Mayıs Üniversitesi, Veteriner Fakültesi, Fizyoloji Anabilim Dalı, Samsun, Türkiye.
}

Geliş Tarihi: 06.01.2017

Kabul Tarihi: 15.02.2017

\begin{abstract}
Özet: Lineer kromozomların uçlarında yer alan telomer adı verilen yapılar kromozomların bütünlüğünü sağlar. Kısa telomerler, DNA hasarında oluşan sinyale benzer bir sinyal üreterek, gerek yaşlanmayı gerekse de programlı hücre ölümünü tetikler. Telomeraz enzimi de kısalan telomerleri onararak telomer zincirlerinin uzun kalmasını sağlar. Böylece hücrelerin bölünme kapasitesinde artış sağlanmış olur. İnsan ve hayvan onkojenik viruslarının, geliştirdikleri mekanizmalarla telomeraz enzimini yeniden aktive edebildikleri ispatlanmıştır. Bu derleme viral enfeksiyonlar ile telomeraz aktivitesi arasındaki ilişkinin incelendiği bir dizi çalışmadan hazırlanmıştır.
\end{abstract}

Anahtar Kelimeler: Viral enfeksiyonlar, Telomer, Telomeraz.

\section{Telomerase Activity in Viral Infections}

\begin{abstract}
The structures at the ends of linear chromosomes called telomeres provide the integrity of the chromosomes. Short telomeres produce a signal similar to DNA damage and triggering both programmed cell aging and programmed cell death. Also, telomerase enzyme restores shortened telomeres and allowing telomerase chains to stay longer. Thus increases the cleavage capacity of the cells. It has been proven that human and animal oncogenic viruses can re-activate telomerase enzyme in the cell through their new developed mechanisms. This review is prepared with series of studies that is examined the relationship between viral infections and telomerase activity.
\end{abstract}

Keywords: Viral infections, Telomer, Telomerase.

\section{Giriş}

Telomerler, kromozomların son kısmını rekombinasyon, yıkım ve füzyon gibi durumlara karşı koruyarak, kromozomların bütünlüğü ile stabilitesini sağlayan yapılar olarak tanımlanmaktadır (Riethman ve ark., 2001). Kromozomlar konusundaki ilk çalışmalarda terminal bölgede delesyon ve inversiyonların az sayıda olduğu bildirilmiş, ilerki çalışmalarda ise kromozomların bütünlüğünün telomerler tarafından sağlandığı belirlenmiştir (Blasco, 2005). Büyük looplar (ilmek) halinde son bulan telomerlerin, T-loop yapısının, telomerin kendi üzerine kıvrılmasıyla, D-loop yapısının ise; guanince zengin tek ipliğin (G-kuyruğu) çift iplikli telomerin içine girip, telomer ipliklerinden birinin yerine geçmesiyle oluştuğu bilinmektedir (Neumann ve Reddel, 2002). Telomerin T-loop yapısına bağlı olarak bulunan, yapının stabilitesini sağlayan ve kromozomal uçların DNA hasarı olarak algılanmasını önleyerek, bu uçları koruyan 6 adet protein vardır. Bunlar TRF1 (Telomer Tekrar Faktör 1), TRF2 (Telomer Tekrar Faktör 2), POT1 (Telomer koruyucu 1), TIN2, TPP1 (tripeptidyl peptidaz 1) ve Rap1 (Represör Aktivatör Protein), "Shelterin" kompleksini meydana getirmektedir (Şekil 1) (De Lange, 2005). TRF1, TRF2 ve TIN2 proteinleri, telomerazın tutunmasını bloke ederek telomerik kısalmaya neden olduklarından, telomerlerin negatif regülatörleri, РОT1 ve TTP1 proteinleri ise telomerlerin pozitif regülatörleri olarak kabul edilir (Smogorzewska ve De Lange, 2004).

Son yıllarda yapılan çalışmalarda telomerlerde G-quadruplex (G- tetrad veya G4- DNA) yapılarının varlığı da tespit edilmiş ve G-4 DNA'yı stabilize eden ve telomeraz aktivitesini durdurabilen bileşiklerin kanser terapisinde kullanılabileceği de ileri sürülmüştür. (Smith ve Johnson, 2010).

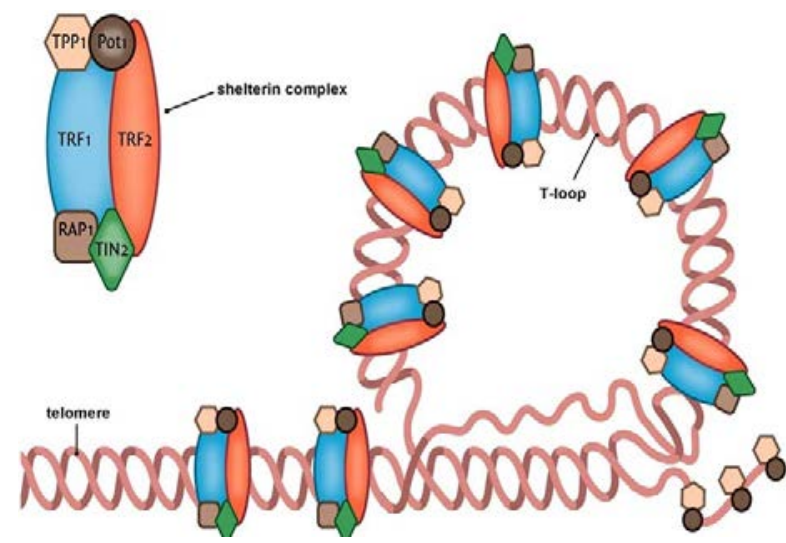

Şekil 1. Telomerde "shelterin" kompleksi (De Lange, 2005).

Telomer Uzunluğu ve Telomeraz: Doku kültürü çalışmaları sırasında gözlemlenen telomer kısalmasının, somatik hücrelerde çoğalmayı sınırlayıp hücre yaşlanmasına, hatta ölüme yol açabilecek 
değişikliklere neden olduğu bildirmiş ve laboratuvar araştırmaları sırasında hücrelerin bir kaç bölünmeden sonra çok fazla telomer nükleotiti kaybettiği için ölerek araştırmalarda sıkıntıya neden olduğu da ifade edilmiştir (Ramunas ve ark., 2015). Hücrelerde tespit edilen bu bölünme sınır sayısı "Hayflick Limiti" olarak adlandırılmaktadır (Eskiocak, 2007). Ayrıca, kısa telomerlerin DNA hasarına benzer bir sinyal üreterek, gerek yaşlanmayı gerekse de programlı hücre ölümünü tetiklediği, ölüm zamanına da biyolojik bir iç saat olan "Telomer Uzunluğunun" karar verdiği de ortaya konulmuştur (Jiang ve ark., 2013). Organizmada kısalan telomerleri onarmakla görevli telomeraz enzimi bulunur ve telomer zincirlerinin uzun kalmasını sağlar. Telomeraz (telomer deoksinükleotidil transferaz, telomer terminal transferaz), ribonükleoprotein yapıda, kromozomal uçlardaki "TTAGGG" tekrarlarının sentezinden sorumlu özel bir DNA polimerazdır ve kromozomların sonundaki telomerlerden salgılanır. Telomeraz enziminin protein alt birimi olan telomeraz revers transkriptaz (TERT) ise telomerazın aktivitesini belirler. Telomeraz, bir hücrede ne kadar aktif ise, telomeri de o kadar uzun olur ve telomerlerin uzun olması hücrelerin bölünme kapasitesini artırır (Griffith ve ark., 1999).

Telomeraz ve Viral Enfeksiyonlar: Telomeraz aktivitesi ile insan ve hayvan tümör viruslarının ilişkisinin incelendiği çalışmalarda hücresel dönüşüm ve karsinogenezisteki telomeraz fonksiyonları belirlenmeye çalışımıştır. Telomeraz aktivitesinde kodlanmayan viral RNA'ların (ncRNAs) ve konak hücre ncRNA'larda virus kaynaklı değişikliklerin destekleyici rol oynadığı bildirilmiştir (Hartwig ve ark., 2014). Bu çalışmalarda Epstein-Barr virusunun (EBV), Kaposi sarkomaya neden olan herpes virusun, insan papilloma virusunun (HPV), hepatit $B$ virusunun (HBV), hepatit $C$ virusunun (HCV) ve insan T-hücreli lösemi/lenfoma virüsü tip 1 (HTLV-1)'in telomeraz transkripsiyonunu arttırabildiği görülmüştür (Bellon ve Nicot, 2008). Ayrıca, Hepatit B ve Hepatit C pozitif hastalarından alınan doku biyopsileri, normal karaciğer dokusu ile karşılaştırıldığında telomeraz aktivitesinin yüksek olduğu bildirilmiştir (Miura ve ark., 1997). Araştırmacılar, nazofarenks karsinomu olan hastalardan alınan örneklerin analizinde ise \%97.5 EBV pozitifliği ve \%94.9 oranında da telomeraz pozitifliği olduğu sonucuna ulaşmışlardır (Kerekhanjanarong ve ark., 2000). EBV ile B-lenfoblastoid hücre hatlarının analizi sonrasında da telomeraz aktivitelerinin yüksek olduğu da bir başka çalışma ile gösterilmiştir (Bellon ve Nicot, 2008). Araştırıcılar, insan kaposi sarkomu ile ilişkili herpesvirus 8 (KSHV/ HHV-8) ile enfekte olan endotel hücrelerini enfekte olmamış hücreler ile karşılaştırıldıklarında ise yüksek telomeraz aktivitesine sahip olduklarını bildirmişlerdir (Flore ve ark., 1998).

Hayvan viruslarından Marek hastalığı virusu (MDV) ile tavuklarda yapılan çalışmalarda ise virusun çok az miktarda telomeraz ribonükleoprotein kompleksi, revers transkriptaz aktivitesi (TERT) ve bir RNA alt birimi (TR) ile bir protein altbirimi içerdiğini gösterilmiştir (Shkreli ve ark., 2007). Ayrıca, MDV enfeksiyonu sırasında viral RNA alt birimlerinin (VTR) telomeraz aktivitesini arttırarak Thücresi ölümsüzleşmesine neden olduğu, yani diğer bütün onkojen virusler gibi MDV'nin de telomeraz aktivitesini arttırdığı görülmüştür (Fragnet ve ark., 2003). Bovine Leukemia Virus (BLV) ile enfekte hayvanlarda da telomerase aktivitesinin arttığı bildirilmiştir (Szczotka ve Kuzmak, 2013). Ayrıca bir başka çalışmada BLV enfeksiyonunun persiste lenfositozis aşamasında yada gözle görülebilir tümörlerin tespiti sırasında telomeraz aktivitesinin yükseldiği ve bu yükselişin istatistiksel olarak anlamI bulunduğu da bildirilmiştir (Hemmatzadeh ve ark., 2015). Ayrıca bazı tümör viruslarının telomeraz ve telomer uzunluğunun düzenlenmesinde etkili olduğu hatta bazı virusların virus ve konakçısı arasındaki karmaşık ilişkiyi düzenlerken telomerazın negatif olması için ek bir mekanizma geliştirdikleri ve bir çok tümör virus proteininin, hücrenin telomeraz ekspresyonunu artırmak için transkripsiyon faktörleri gibi hareket ettiğini de belirlenmiştir (Bellon ve Nicot, 2008). Örneğin, HBV'un transaktivatör onkoproteininin ( $\mathrm{HBV} \mathrm{X}$ ) karaciğer hücrelerindeki telomeraz ekspresyonunu ve telomeraz aktivitesi arttırdığı gösterilmiştir (Zhang ve ark., 2005). EBV ile kodlanan latent membran proteini-1'in (LMP1) ise, temel hücre içi sinyal yollarından olan nükleer faktör kappa $B$ (NF-kB) ve JAK/STAT sinyal yollarını kullanarak apopitozisi önleyip karsinogenez tümör aktivasyonuna neden olduğu ortaya konmuştur (Zheng ve ark., 2007). Ayrıca, araştırmalarla, EBV enfeksiyonu sırasında saptanan artmış telomeraz aktivitesinin, epitel hücrelerinin EBV ile enfeksiyonuna katkı sağladığı da belirlenmiştir (Rac ve ark., 2015). EBV ile enfekte nazofarengeal epitel hücrelerinde ve B-hücresi lenfomalarında ise LMP1'in telomeraz aktivitesi artışından sorumlu olduğu ve LMP1'in ekspresyonunun EBV-negatif bir nazofarengeal karsinom hücresinin hTERT protein ekspresyonunu da arttırdığı bildirilmiştir (Mei ve ark., 2006). EBV latent membran proteini 2A'nın (LMP2A) negatif düzenleyici bir hTERT promotörü gibi hareket edebildiğini de tespit edilmiştir (Chen ve ark., 2005). Bir başka çalışmada ise, EBV' a bağı tümör gelişiminde, TERT ekspresyonu ve telomeraz aktivasyonunun kritik rol oynadığı bildirilmiştir. (Dolcetti ve ark., 2014). 
Kuşlarda da tıpkı insanlarda olduğu gibi embriyonik dönemde ve gelişmekte olan organlarda telomeraz aktivitesi mevcut iken somatik dokularında ise yok denecek kadar azdır (Delany ve Daniels, 2003). Hayvan viruslarından MDV' nin bilinen ilk fonksiyonel telomeraz RNA alt birimini kodlayan virus olduğu da ifade edilmiştir (Shkreli ve ark., 2007). Ayrıca, yapılan çalışmalarda Avin Leukosis Virus'un (ALV) viral LTR'sinin (uzun terminal tekrarları) özellikle ters yönde, telomeraz promotör aktivitesini arttırdığı TERT transkripsiyon üzerinde dolayısıyla da telomeraz aktivitesinde doğrudan düzenleyici etkisi olduğu sonucuna varılmıştır (Feng ve ark., 2007).

$\mathrm{Bu}$ veriler ışığında telomeraz ve hücre yaşlanması üzerinde çalışan araştırmacılar ise, Simian Virus 40 (SV 40), insan papillomavirus (HPV) ve adenovirus gibi DNA tümör virusları ile transformasyon sonrası hücre yaşlanmasının önüne geçilebileceğini bildirmişlerdir. Ayrıca tümör viruslarında, hücredeki p53 ve p110RB gibi hücresel tümör baskılayıcı proteinlere bağlanarak onları inaktive edebilen proteinler olduğunu da ortaya konmuştur. Hücresel tümör baskılayıcı proteinlerde meydana gelen bu inaktivasyon, viruslar tarafından transforme edilen hücrelerin uzun hayat döngüsünü de açıklamaktadır. Hatta mutasyonlar ve gen delesyonları nedeniyle, pek çok ölümsüz hücrede p53 ve p110RB proteinlerinin bulunmadığı da saptanmıştır (Bryan ve Reddel, 1997).

\section{Sonuç}

Sonuç olarak, insanlarda ve hayvanlarda telomer uzunluğunun ve telomeraz aktivitesinin kanser, yaşlanma ve ölüm ile yakından ilişkili olduğu görülmektedir. Kısa telomerlerin DNA hasarına benzer bir sinyal üreterek, gerek yaşlanmayı gerekse de programlı hücre ölümünü (apoptozis) tetiklediği, ölüm zamanına da biyolojik bir iç saat olan "Telomer Uzunluğunun" karar verdiği de bu konudaki önemli verilerdendir. Ayrıca insanların ve hayvanların somatik hücrelerinde yok denecek kadar az olan veya hiç varlık göstermeyen telomeraz aktivitesine karşın onkojenik viruslerle enfekte olmuş hücrelerde telomeraz aktivitesinin yeniden başladığı ve bunun hücre yaşlanmasının önüne geçilebileceği iddia edilmektedir. Ancak, onkojen hayvan virusları ile ilgili bu konudaki çalışmalar sınırlıdır. Genellikle insanlar için patojen olmayan bu viral etkenlerin, telomeraz aktivitesi üzerine etkileri ve bu etkenlerin hücre yaşlanması ve kanserin ortadan kaldırılması konusundaki etkilerinin daha ayrıntılı olarak araştırtılması önerilmektedir.

\section{Kaynaklar}

Bellon M, Nicot C, 2008: Regulation of Telomerase and Telomeres: Human Tumor Viruses Take Control. J Natl Cancer Inst,100, 98-108.

Blasco MA, 2005: Telomeres and Human Disease: Aging, Cancer and Beyond. Nature Reviews: Genetics, 6, 611-22.

Bryan TM, Reddel RR, 1997: Telomere Dynamics and Telomerase Activity in In vivo Immortalised Human Cells. Europ J Canc, 33, 5, 767-73.

Chen F, Liu C, Lindvall C, Xu D, Ernberg I, 2005: EpsteinBarr virusu, latent membran 2A (LMP2A) telomeraz epitel hücre hatlarında transkriptazı (hTERT) ters aşağı regüle. Int J Cancer, 113, 284-289.

De Lange T, 2005: Shelterin: the protein complex that shapes and safeguards human telomeres. Genes Dev, 19, 2100-2110.

Dolcetti R, Giunco S, Col DJ, Celeghin A, Mastorci K, De Rossi A, 2014: Epstein-Barr virus and telomerase: from cell immortalization to therapy. Infectious Agents and Cancer, 9, 8.

Eskiocak U, 2007: Investigation of telomerase activitiy in diagnosis of endometrial and cervical cancer. Yüksek Lisans tezi, ODTÜ Fen Bilimleri Enstitüsü, Ankara.

Feng Y, Xian RR, Li Y, Polony TS, Beemon KL, 2007: Telomerase reverse transcriptase expression elevated by avian leukosis virus integration in B cell lymphomas. Proc Natl Acad Sci, 104,18952-18957.

Flore O, Rafii S, Ely S, O'Leary JJ, Hyjek EM, Cesarman E, 1998: Transformation of primary human endothelial cells by Kaposi's sarcoma-associated herpesvirus. Nature, 394, 588-592.

Fragnet L, Blasco MA, Klapper W, Rasschaert D, 2003: The RNA subunit of telomerase is encoded by Marek's disease virus. J Virol, 77, 5985-5996.

Griffith DJ, Corneau L, Rosenfield S, Stansel RM, Bianchi A, Mossus H, De Lange T, 1999: Mammalian telomeres an in a large duplex loop. Cell, 97, 503-514.

Hartwig FP, Goedert L, Wagner MS, Schultze E, 2014: Tumor Cell Development: A Role for Viruses and Telomerase Activity? Advances in Tumor Virology, 4, 7-16.

Hemmatzadeh F, Keyvanfar $\mathrm{H}$, Hasan NH, Niap F, Bani Hassan E, Hematzade A, Ebrahimie E, McWhorter A, Ignjatovic J, 2015: Interaction between Bovine leukemia virus (BLV) infection and age on telomerase misregulation. Vet Res Commun, 39, 2, 97-103.

Jiang J, Miracco EJ, Hong K, Eckert B, Chan $\mathrm{H}$, Cash DD, Min B, Zhou ZH, Collins K, Feigon J, 2013: The architecture of Tetrahymena telomerase holoenzyme. Nature, 496.

Kerekhanjanarong V, Sitawarin S, Sakdikul S, Saengpanich $S$, Chindavijak S, Supiyaphun P., Voravud N, Mutirangura A, 2000: Telomerase assay and nested polymerase chain reaction from nasopharyngeal swabs for early noninvasive detection of nasopharyngeal carcinoma. Otolaryngol Head Neck Surg, 123, 624-629. 
Mei YP, Zhu XF, Zhou JM, Huang $H$, Deng R, Zeng YX, 2006: siRNA targeting LMP1-induced apoptosis in EBV-positive lymphoma cells is associated with inhibition of telomerase activity and expression. Cancer Lett, 232, 189-198.

Miura N, Horikawa I, Nishimoto A, Ohmura H, Ito $H_{\text {, }}$ Hirohashi S, Shay JW, OshimuraM, 1997: Progressive telomere shortening and telomerase reactivation during hepatocellular carcinogenesis. Cancer Genet Cytogenet, 93, 56-62.

Neumann AA, Reddel RR, 2002: Telomere maintenance and cancer? look, no telomerase. Nature Reviews Cancer, 2, 879-884.

Rac J, Haas F, Schumacher A, Middeldorp JM, Delecluse HJ, Speck RF, Bernasconi M, Nadal D, 2015: Telomerase Activity Impacts on Epstein-Barr Virus Infection of AGS Cells. Plos One, 10, 4, 1-24.

Ramunas JE, Yakubov JJ, Brady SY, Corbel C, Holbrook M, Brandt J, Stein JG, Santiago JP, Cooke HMB, 2015: Transient delivery of modified mRNA encoding TERT rapidly extends telomeres in human cells. The FASEB Journal, 29, 5, 1930-1939.

Riethman HC, Xiang Z, Paul S, Morse E, Hu XL, Flint J, Chi HC, Grady DL, Moyzis RK, 2001: Integration of Telomere Sequences with the Draft Human Genome Sequence. Science, 409, 948-950.
Shkreli M, Dambrine G, Soubieux D, Kut N, Rasschaert D, 2007: Involvement of the Oncoprotein c-Myc in Viral Telomerase RNA Gene Regulation during Marek's Disease Virus-Induced Lymphomagenesis. J Virol, 81, 9, 4848-4857.

Smith JS, Johnson FB, 2010: Isolation of G-Quadruplex DNA Using NMM-Sepharose Affinity Chromatography. Methods Mol Biol, 608, 207-21.

Smogorzewska A, De Lange T, 2004: Regulation of telomerase by telomeric proteins. Annu Rev Biochem, 73, 177-208.

Szczotka M, Kuzmak J, 2013 Telomerase activity and telomere length in cattle infected with bovine leukemia virus (Blv). J Comp Pathol, 148, 70.

Zhang X, Dong N, Zhang H, You J, Wang H, Ye L, 2005: Effects of hepatitis $B$ virus $X$ protein on human telomerase reverse transcriptase expression and activity in hepatoma cells. J Lab Clin Med, 145, 98104.

Zheng H, Li LL, Hu DS, Deng XY, Cao Y, 2007: Role of Epstein-Barr virus encoded latent membrane protein 1 in the carcinogenesis of nasopharyngeal carcinoma. Cell Mol Immunol, 4, 185-196.

*Yazışma Adresi: Semra OKUR GÜMÜŞOVA Ondokuz Mayıs Üniversitesi, Veteriner Fakültesi, Viroloji Anabilim Dalı, Samsun, Türkiye e-mail: semragumusova@hotmail.com 